\title{
The Influence of Vocational and Technical Education towards 6- 3-3-4 System of Education for National Development
}

\author{
Dr Ogunmola M.O ${ }^{1 *}$, Ogunmola Oluwafemi Samuel ${ }^{2}$ \\ ${ }^{l}$ Department of Fine and Applied Arts Education Bamidele Olumilua University of Education, Science, and \\ Technology, Ikere Ekiti, Ekiti State, Nigeria \\ ${ }^{2}$ Department of Accounting, University of Benin, Edo State, Nigeria
}

*Corresponding Author: Dr Ogunmola M.O, Department of Fine and Applied Arts Education Bamidele Olumilua University of Education, Science, and Technology, Ikere Ekiti, Ekiti State, Nigeria

\begin{abstract}
The study investigated the influence of Vocational and Technical Education toward 6-3-3-4 system of education for national development. Vocational and Technical Education has been integral part of national development strategies in many societies because of the impact on human resource development, productivity and economic development. The 6-3-3-4 system of education tends to direct Nigeria towards social, political, cultural and economic realities of the nation. The broad aim of education under the system is to provide all Nigerian learners a wide variety of education and vocational and technical education opportunities to ensure the optimum development of their potential. Evidence indicates that the implementation of the 6-3-3-4 system in Nigerian schools, including schools for the deaf, remains unsatisfactory. National developments as well as strategies for achieving sustainable development in Nigeria are the focus.
\end{abstract}

Keywords: Vocational and Technical Education, 6-3-3-4 System of Education and National Development

\section{INTRODUCTION}

In Nigeria, technical education had a slow start and developed less quickly than literacy education, which was pioneered by the voluntary agencies. This was partly because it is much more expensive in terms of staff and equipment, and because 'the Christian missions were more interested in a native's ability to read the Bible than in his ability to turn screws and prime water-pumps' (Fafunwa, 2014). Technical and Vocational Education, Training has been regarded as the bedrock to sustainable technology development programs in entrepreneurship, occupational professionalism, self-reliance, poverty alleviation, wealth creation and others. Consequently, Technical and Vocational Education, Training focuses on specific trades that prepare an individual to be self-reliant and suitable for employment. Ajokporise (2010) posited that Technical and Vocational Education, Training focuses on specific trades such as automobile repairs, welding and fabrication, plumbing and pipefitting, electrical craftsmanship, hair dressing, tailoring, barbing among others. Furthermore, Ojimba (2012) stated that the contributions of Technical and Vocational Education, Training ranges from mechanical/automobile technology, electrical and electronic technology, building, woodwork technology, metalwork technology, fine and applied arts etc.

In 1977, when the National Policy on Education (NPE) was first published, the issue of acquisition of practical skills to make students more self-reliant was incorporated (FRN, 2017). The 6-3-3-4 (6 years of primary education, 3 years each of Junior and Senior secondary education, and 4 years of Higher education) system of education implemented in 1982 should have been a self-reliant policy but, in reality, it was not to be because of the gap between the policy document and the implementation, including a dearth of qualified and competent teachers; infrastructure decay; lack of standardization and development of non-formal vocational and technical education; and a low level of funding for the programmes. Vocational and technical education, no doubt, can serve as a bail-out from unemployment, underdevelopment and it can boost the economy of any nation if properly implemented are monitored (FRN, 2013).

According to Gusua (2008), crises in education started when government went out to implement the 6-3-3-4 system without adequate planning put in place. Gusua (2008) further stated that pre- 
vocational subjects meant to lunch Nigeria into a respectable industrialized state with abundant pool of lower manpower became a mirage. The teaching of prevocational subject ended up not having either workshop or qualified teachers. VTE subjects (where possible) were theoretically taught like social studies. The hopes that reforms will enable schools fabricate some of their basic needs such as chairs, desks beds, etc. never materialized.

Nigerian systems of education at all levels have witnessed dramatic changes in terms of purpose, organization, structure and changes in nomenclature of certificates awarded. For instance, 1970's to early 1980s witnessed the 6-5-4 system of education; late 1980s to 2005 witnessed a restructuring of the education system on a 6-3-3-4 system while 2008 witnessed a new reform of 9-3-4 system of education. The various reforms in education are reflected in the National Policy on Education (NPE) document.

In the views of Thompson, (2002) vocational education aims at the development of human abilities in terms of knowledge, skills and understanding so efficiently in carrying on the activities in the vocational pursuits of his choice. Winer, (2000) in his contribution opined that vocational education is designed to develop skills, abilities, understanding attitudes, work habits and appreciation encompassing knowledge and information needed by workers to enter and make progress in employment on a useful and productive basis. It is an integral part of the total education programme and contributes towards the development of good citizens by developing their physical, social civic, cultural and economic competencies.

National development is not just a matter of getting more money into the hands of the poor, but ensuring that increased production, and its resulting increased income, leads to an improved standard of living (lsiugoAbanihe, lsamah and Adesina, 2002). Every meaningful, concrete and lasting development begins and ends in the focus on human resources. Human resources refers to all economic resources that are wholly and directly supplied by human beings, this includes the suppliers of labour services and entrepreneurial function (Onyeka, 2010). The size of the human resources depends largely on the population size while the quality is a product of educational, health services and environmental factors (conducive environment that promotes an investment friendly platform).

\section{CONCEPT OF Vocational EdUCATION IN Nigeria}

The term vocational and technical education has been defined differently by many authors. Some authors define separately while others defined the twin concept jointly. Oranu (2013), saw vocational and technical education as "skill-based programme designed for sub-professional level education and based on a specific vocation. Technical education, on the other hand facilitates the acquisition of practical and applied skills as well as basic scientific knowledge. The major difference between the two terms according to Oranu (2013) is that vocational education gives general technical knowledge. Thus, while every vocational education programme is technical in nature, not all technical education is vocational. This subtle relationship accounts for the interchangeable use of both terms in academic literature".

The Federal Republic of Nigeria ((2004) through the National Policy on Education (NPE) (2004) UNESCO in Ayonmike, Okwelle and Okeke (2015) defined VTE as those aspects of educational processes involving in addition to general education, the study of technologies and related sciences and the acquisitions of the economy and social life. The NPE which came into existence as a result of the national curriculum conference of 1969 further stated that VTE is an integral part of general education and also a means of preparing people for occupational fields and for effective participation in the world of work. It is an aspect of life learning and a preparation for responsible citizenship; an instrument for promoting environmentally sound suitable development and a method of alleviating poverty.

Vocational and technical education according to Okorocha (2012) is an educational training which encompasses knowledge, skills, competencies, structural activities, abilities, capacities and all other structural experiences for securing jobs in various sector of the economy or even enabling one to be self-dependent by being a job creator. Vocational and technical education according to ILO in Oluwale, Jegede and Olamade (2013) is a vehicle for the development of marketable and entrepreneurial skills and engine of development. Amoor (2009) saw it as the core of both individuals and society's economy. The author further stressed that through the acquisition of skills; individuals 
could explore their environment and harness the resources within it, which could serve them and the society since the wealth of any nation determines its development.

Vocational and technical education in view of Ojimba (2012) is a forms of education whose primary aim is to prepare persons for employment in recognized occupation and this encompasses field of study (Agricultural education, fine and applied arts education, business education and vocational trades in soap making, hairdressing, computer training among others). Iheanacho (2006) defined vocational education as that aspect of education that deals with business education, farming, book keeping, bricklaying, among others with aims of acquiring vocational skills in these fields. Uwaifo (2009) posited that technical education is the training of technically- oriented personnel who are to be initiators, facilitators, and implementers of technological literacy that would lead to self-reliance and sustainability. The author stresses that technical education has direct impact on national welfare. Banjoko cited in Dokubo (2013) summed it all stressing that skill is a major distinguishing aspect of vocational education which makes it outstanding from liberal arts. In summary, vocational and technical education essentially develops in the individual the knowledge, skills, and desirable attitude for legitimate work.

\section{ROLES Of VOCATIONAL AND TECHNICAL EDUCATION}

Vocational and technical education is not just a Nigerian issue. It has been a long time discourse both in academic and practice. Through the issue in most developing countries like Nigeria has been a question of successful implementation of VTE programme (Okorocha, 2012). In this era of globalization and Information and Communication Technology (ICT), emphasis is on vocational skills for the production of self-reliant citizens. VTE therefore, has the following roles to play: Youth Empowerment In this 21 st century characterized by knowledge explosion, the emphasis should be on production of self-reliant citizens. VTE should empower the Nigerian youth with requisite employability skills that should be sustained. VTE schools should produce men and women who, at the end of their education should be able to put into use the skills they have acquired while in school. Institutions should partner with industries and other businesses to enable students fit into the wider society on graduation, either as individual workers in paid employment or self-employed person and functional members of the political society.

VTE should also empower the people socially and economically so that they will be able to participate in the making of decision regarding policies affecting their lives, to make the citizens and nations to be self-reliant in the production, distribution and consumption of goods and services. Ogundele, Akingbade and Akinlabi (2012) revealed that youth empowerment is influenced through acquired skills. Enhancement of Citizens National Economy Vocational and technical education should play a crucial role in the social and economic development of a nation (Grootings and Nelsen, 2006).

According to (King and Palmer, 2000) development of a nation's economy is contingent on the quality of skilled human capital in the pool. Vocational and technical education provides student with life skills that will make them to be productive entrepreneurs as it engenders creative and innovative ideas; enlarges the economic pie and increases personal freedom. The business environment is changing at a fast pace due to the rapid emergence of technology and globalization. This has added to the increase in demand of valuable human skills necessary to respond to such drastic changes for economic progress. As a channel for entrepreneurial skill acquisition, VTE play the role of improving the economic situation of Nigeria through production and distribution of goods in different areas of specialization. This is achievable through the training of the students in different specialized fields.

In the long run, this will help the students to establish their own enterprise as seen in China, Turkey, India, Japan among other countries that have succeeded economically through vocational education. This is in line with the views of Lawal (2014) who opined that "for a country to advance socially, economically and technologically, its citizens must be creative and productive with a majority becoming job creators rather than seekers". The author concluded by emphasizing that optimum attention and recognition is to be giving to the promotion of VTE in Nigerian if the country wants to attain great achievement of productivity and sustainable economic environment and natural development. According to Sheieh, Wang and Chon (2009), lifelong vocation education will gradually improve the economic and social development of both the people and the country by making vocational education a channel for exploitation of human resources. 
Ozasagir, Bayraktutan and Arsian (2010), their regression and causality test carried out in turkey provided empirical support for a positive relationship between vocational education and industrial productivity. Vocational trainees' productivity will contributed to domestic economic activities. Provision of guidance and Counseling Services to the Students: vocational and technical education should equip students with the right skill for effective adaptation to the business environment (Okafor, 2011). However, no student can acquire all the skills needed in every aspect of the economy. Therefore vocational education practitioners have a role to play in terms of observing and monitoring students' behaviors, attitudes and actions within the environment for proper skill alignment. The behaviour observed with help VTE practitioners to counsel, guide and advice students on their choice of skills. This will help to ensure that students enrolled in appropriate callings for effective performance and sustainability of the skills learnt. With proper guidance and counseling, students can acquire skills in dealing with finance and accounting matters, economics, business, ICT, fine and applied arts, music and entertainment, building, auto-mobile, woodwork, electrical and electronics, metal works and agricultural activities such as fishery, poultry, snarling, piggery, crop planting among other numerous skills that will make them self-reliant, self-dependent, self fulfilled and selfactualized.

\section{CONCEPT OF 6-3-3-4 SYSTEM OF EDUCATION}

The introduction of the 6-3-3-4 system of education according to Fabunmi (2016) pre-supposed that the old system of education (6-5-4) was archaic, whereas the new system is modern, dynamic and progressive. It should be recalled that early education policies failed to provide Nigerian goals and objectives because it placed great emphasis on paper qualification. However, for the proper understanding of 6-3-3-4 system of education, it is necessary to state the national objectives and philosophy of education which include:

a. a free democratic society;

b. a just and egalitarian society

c. a united, strong and self-reliant nation,

d. a great and dynamic economy,

e. a land full of bright opportunities for all citizens. (FRN, 2004)

It is believed that the above objectives were geared towards self-realization, better human relationship, national consciousness, national unity as well as social, cultural, economic, political, scientific and technological progress. Howbeit, it needed to say that the system 6-3-3-4 (Fabunmi, 2016) has helped in these areas:

(i) It has assisted in the attainment of some of the objectives of National policy on education i.e. emphasis is now placed on yearning and aspirations of Nigerian society

(ii) Students (both boys and girls) to some extent are now staying longer in schools

(iii) The system has produced more matured youths who are able to take decisions on their own.

(iv) The system has reduced to some extent the rate of dropout in schools as opportunities are made available for students to develop their talents to the fullest.

(v) The system has helped Nigeria nation to develop technologically as we have various technical colleges, polytechnic and universities of technology in the country today that have produced more technicians and technologists.

(vi)The system to some extent has helped in catering for individual differences which presupposes differences in intelligence, physical ability, interest and individual achievement oriented goal and aspirations. This affords the individual learner the opportunity to develop his/her potentials

However, with all these lofty achievements, the system has failed. It is an understatement that the system of education being implemented in Nigeria today has lost the quality of 6-3-3-4 (Uddin, 2009). If not for a handful of Nigerians who, through dint of handwork, still reflect the indices of being educated, we should be talking of a total collapse of the sector. The following are the predicaments to its proper execution: 
(i) Problem of implementing the language policy, this arises as a result of non-availability of adequate textbooks for the language as well as shortage of teachers.

(ii) Political problem: The idea for the system was conceived by military government that favoured centralization. However, there has been change(s) in the leadership structure of the nation which eventually prevented co-oriented approach at the implementation of the policy.

(iii) Financial problem: Since the success of any educational programme depends heavily on fund made available, most of the equipments and facilities required for the system could not be bought as they are to be imported from abroad.

(iv) Public Enlightenments: The general public seemed to be unaware of the benefit of the programme, hence it becomes a failure.

(v) Inadequate statistics: There is an inability to obtain detailed and up-to-date statistical data needed for effective educational planning.

Uddin (2009) who examine the implementation of the technology subjects' aspect of the 6-3-3-4 system of education using Ekpoma a city in Nigeria as a case study. These authors find significant problems with program implementation and also a deficit of personnel and materials to support the system. Imam (2012) reviews educational policy in Nigeria since 1944, highlighting details about the 6-3-3-4 system and its implementation. The three aforemention papers though useful do not evaluate this system's welfare impacts empirically although each provides some evidence and (or) arguments about the documented problems/issues with the system. This gap in the literature is one of the underlining motivations for this paper. We focus on the impact of the education system change on individuals' poverty risk, wages and employability primarily because of the clear link between the 63-3-4 system's goals and objectives and these outcomes.

The recognition of the literally and the academic nature of the curriculum of Nigerian schools probably inspired the re-organization of the curriculum and entire school system that gave birth to the 6- 3- 3- 4 system whose goal was to provide option for those who may not proceed to senior secondary as well as provide opportunity for self-employment for those to whom secondary education was terminal. In fact, among the objectives of secondary education was provision of technical knowledge and vocational skills necessary for agricultural, industrial, commercial and economic development (FGN, 2004).

\section{THE CONCEPT OF NATIONAL DEVELOPMENT}

Development is associated with modernization, material advancement, industrialization scientific and technological progress, the emergence of nuclear energy, electronic and biological revolution, new knowledge about man and the universe. It means urbanization, socio-cultural transformation, mass literacy, vertical and horizontal mobility, employment opportunities and the emergence of specialized and independent occupational roles (Umuru, 2002). A nation is a large community of people sharing common language, common culture, common history and having a common constitution and government. Nigeria is a nation and the national share common characteristics of a nation such as binding principles and policies.

The ultimate aim of national development must be to bring about sustained improvement in the wellbeing of the individual and bestow benefits to all self-reliance and mobilization of domestic resources, the transformation of the structure of rural production, the development of small-scale industries and the acquisition of technological and scientific skills. These objectives are stale, but well-conceived, planned and directed policies and programmes are required for their realization (Umaru, 2008). This means that developments is about self-reliance in every aspect of national life. As soon as the individual are made to acquire specialized skills that will enable them to help develop the society, then the society becomes developed. This accounts for the difference between the developed countries and the undeveloped nations.

According to Alabi (2008) the major factor responsible for the wide gap in the level of development between the so called developed and the developing nations is the level of development of pure and applied science in these nations. May (2004,) was of the opinion that "development is realistically seen as a multi-dimensional process involving the totality of man in his political, economic, 
psychological and social realties among others". Development is a holistic phenomenon not a concept to be abridged in application or compartmentalized and approached as a uni-dimensional process. Essentially it should be man-oriented and not institutional-oriented. If we focus our attention on the individual citizens we can then think of what he needs at a particular time and how he can combat a number of colonial legacies which have held him down. Ogai (2003) sees national development as a gradual manifestation of positive changes in the economic, industrial, political, social, cultural and administrative life of a country. He also went further to say that in viewing the progress of a country, the term national development is more comprehensive than economic growth. It involves high quality and large quantity of productive resources as well as efficiency in using them.

\section{National DeVelopment Plans In Nigeria}

We have had series of development plans in Nigeria. Nigeria is permanently hunted by the spectre of development. Its forty-nine years of independence actually are rolling by daily in search of development. The myth of growth and development is so entrenched that the country's history passes for the history of development strategies and growth models from colonial times up to date. No term has been in constant flux as development. This seems the only country where virtually all notions and models of development have been experimented (Aremu, 2003). Two years after independence, the first National Development Plan policy was formulated between 1962 and 1968 with the objectives of development opportunities in health, education and employment and improving access to these opportunities, etc. This plan failed because fifty percent of resources needed to finance the plan was to come from external sources, and only fourteen percent of the external finance was received (Ogwumike, 2015).

In order to increase the access of rural dwellers to safe drinking water, rural water supply schemes were planned apart from the huge boreholes drilling Programme. At the state level, the various state governments spelt out different policy issues in the fourth development plan. For instance, according to (Ikotun, 2010) said government identified four cardinal programs for itself. These include free education at all levels, free medical services, integrated rural development and gainful employment.

\section{CONCLUSION}

Relevant literatures were reviewed in this paper in other to convinced that this research work will aid policy makers to correct the anomalies discovered as problems facing the implementation of the 6-33-4 system of education. Improving skill acquisition through vocational and technical education will no doubt solve Nigerian's multiple problems regarding human capital development, empowerment, unemployment and economic instability. Vocational and Technical Education in Nigeria will definitely take a new outlook in line with the trend in the global world.

Vocational and technical education (VTE) is the most viable and reliable instrument for economy transformation. This is why vocational and technical education is placing emphasis on the development of occupational skills needed as preparation for work in order to earn a useful and lawful living through gainful employment. The curriculum of the 6-3-3- 4 system of education is about the best for Nigeria in terms of its perceived contribution to technological development and Industrialization.

\section{RECOMMENDATIONS}

For the success and survival of influence of vocational and technical education toward 6-3-3-4 system of education for national development, the following recommendations are offered:

- Government should increase the budgetary allocation to vocational and technical education. As we know that government cannot do it alone, corporate organizations, parents and alumni associations should assist in providing some of the equipment needed in the training of vocational and technical students.

- Efforts should also be made by the government to see that there is full implementation of the policies concern vocational and technical education. They should make this possible by promulgating laws or sanctioning each state that fails to adopt or implement the policy fully.

- If the 6-3-3-4 policy must achieve its objectives expected of it by government and people of Nigeria, some steps must be taken. Foremost, that the need for gradual and systematic approach 
towards the implementation should be recognized and followed in the spirit of "make haste slowly" Thus, the goals and objectives set must be periodically evaluated to give room for innovations aimed at solving the emerging and unintended consequences .

- The Federal Government should formulate policies to address the imbalance between technical/vocational schools by coming up with a legislation that would enforce the establishment of private vocational institutions rather than universities.

- The curriculum of vocational schools and institutions should be tailored to the need of industries so that the products of vocational training are employable.

- National development policies and strategies such as vision 2020 and national transformation agenda of the Jonathan administration must be pursued with full commitment and vigour by the Nigerian political leadership.

- Government should implement these development policies or strategies and to formulate it.

\section{REFERENCES}

[1] Ajokporise, J. A. (2010). Principles and Methods in Vocational Education, Enugu: Pacific Publishers.

[2] Alabi, A. O. (2008): Managing Resources for Effective Technological Manpower Training in Pure and Applied Science. Proceedings of NBTE 1s1 National Seminar, 12th August, 2008.

[3] Amoor, S.S. (2009). The Challenges of Vocational and Technical Education programme in Nigerian Universities. Retrieved from from: www.abu.edu.ng/publications.

[4] Aremu I (2003). Development and Political Stability in Kwanashie (ed) Politics and Political Power Relations in Nigeria. Lagos. Dat and Partners Logistic Ltd, 12: 248-262

[5] Ayonimike, C.S., Okwelle, P.C. \& Okeke, B.C. (2015). Towards Quality Technical Vocational Education \& Training Programmes in Nigeria: Challenges and Improvement Strategies. Journal of Education and Learning. 4(1), 25-34.

[6] Dokubo, M. (2013). Blogs Sociotechnical Systems not just another Pretty Theory, retrieved on the 19th March, 2011. From https://dap.dav.mil/mglbog/archive/2010/08/24/ socio-technical-systems-not-justanother-p $E$

[7] Egwuela, J. C. (1995). A Development of Vocational and Technical Education and Personnel Development in Nigeria. Nigeria Teacher, Journal of Teacher Education I. 199-205.

[8] Fabunmi, N. P. (2016). Understanding Teachers Professional Competencies for Education Effectiveness. New Owerri: Springfield Publishers.

[9] Fafunwa, B. (2014). African Education in Perspective in Fafunwa, B. \& Aisiku, J.U. (Eds.). Education in Africa: A Comparative Survey. London: Allen and Unwin.

[10] Federal Government of Nigeria (FGN) (2004). The 6-3-3-4 System of Education, Abuja: Federal Government Press.

[11] Federal Republic of Nigeria (FRN) (2004). National Policy on Education. Lagos: National Education Research Development Council.

[12] FRN - Federal Republic of Nigeria (2013). Implementation Guidelines for the Universal Basic Education (UBE) Programme. Abuja: Federal Ministry of Education, p. 22.

[13] FRN - Federal Republic of Nigeria. (2017). National Policy on Education. Lagos: NERDC

[14] Grootings, P. \& Nielsen, S. (2006). Skills Development for Poverty Reduction. Lesson for Policy Learning in Transition Countries. ETF Yearbook 2006 Turn, European Training Foundation.

[15] Gusau, (2008). Educational Reforms in Nigeria: Successful years of Inconsistencies and Confusions, Gusau Educational Development Association (GEDA), Interactive Session held January, 2008.

[16] Iheanacho, E.N.O (2006). Technical and Business Education for Socioeconomic and Political Stability in Nigeria. International Journal of Research and Education. 3(1). 164-168.

[17] Ikotun, J. (2010). The Role of Education in Career and Vocational Education Development. In Jude E. (Ed) Educational and Vocational Guidance, Concepts and Approaches. Lagos: Grace Publishers.

[18] Imam, D. E. (2012). A Critical Assessment of the Role/Importance of Non-Formal Education to Human and National Development in Nigeria: Future Trends. International Journal of Scientific Research in Education, 5(2), 71-93.

[19] King, K, \& Palmer, R. (2206). Skills Development and Poverty Reduction: the State of the Art, Post Basic Education and Training Working Paper no. 7, Centre of African Studies, Edinburgh University. 
[20] Lawal, A. W. (2014). Technical and Vocational Education, a tool for National Development in Nigeria. International Journal of Social and Humanistic Sciences, 14(1), 53-59.

[21] lsiugoAbanihe, T. lsamah, P. and Adesina, A. (2002). Vocational and Technical Education in Nigeria, Issues and Analysis, Owerri: Noble Publishers.

[22] May, I. C. (2009). Issues and Problems in Implementation of Vocational Education Programmes in Nigeria. Ilesha: Joja Educational Research and Publishers.

[23] Ogai, I. (2003). Incorporating Entrepreneurship Education into Secondary School Curriculum: An Effective Preparation for Youths for Self-Reliance. African Journal of Educational Research and Development, 3(2), 370-375.

[24] Ogundele, O.J.K., Akingbade , W.A. \& Akinlabi, H.B. (2012). Entrepreneurship Training and Education as Strategic Tools for Poverty Alleviation in Nigeria. American International Journal of Contemporary Research, 2(1), 148-156.

[25] Ogwumike F (2015). The Effects of Macrolevel Government Policies on Rural Development and Poverty Alleviation in Nigeria. Ibadan J. Soc. Sci., 1(1): 85-101.

[26] Ojimba, P.D. (2012). Vocational and Technical Educational in Nigeria: Issues Problems and Prospects. Dimension (IPP) Journal of Education and Social Research, Rome, Italy, 2(9), 23-30.www.mcser.org.

[27] Ojimba, P.D. (2012). Vocational and Technical Educational in Nigeria: Issues Problems and Prospects. Dimension (IPP) Journal of Education and Social Research, Rome, Italy, 2(9), 23-30.www.mcser.org.

[28] Okafor, E.E. (2011). Youth Unemployment and Implication for Stability of Democracy in Nigeria. Journal of sustainable Development in Africa, 13(1), 358-373.

[29] Okorocha, E. M. (2012). Teacher Education: A Critical Appraisal of Nigerian National Policy on Education and its Implementation. The Nigerian Teacher Today. I(2) 28-33.

[30] Oluwale, B.A., Jegede, O.O. and Olamade O.O. (2013). Technical and Vocational Skills, Depletion in Nigeria and the need for policy intervention. International Journal of Vocational and Technical Education 5(6), 100-109.

[31] Onyeka, P. E. (2010). Resources for Technical Education in Technical Colleges of Enugu State: in G. C Obodo (Ed); Stress and Crisis in Science and Technology Education in Nigeria. Enugu: Rejoin Publishers.

[32] Oranu, R. N. (2013). Vocational Education and Manpower Development, Vocational/Technical Education Manpower Development NVA p. 1-4.

[33] Ozasagir, A. Bayraktan, Y. and Arslan. I. (2010). The Relationship Between Vocational Education and Industrial Production in Turkey. International Journal of Economic Perspectives, 4(2), 439-448.

[34] Shieh, C.J., Wang, I.M \& Chou, J.R. (2009). The Impact of Vocational Education on Human Resource Development in North China. International Journal of Organizational Innovation, 289-319.

[35] Thompson, C. (2002). Towards a Relevant Technical Education Curriculum in Nigeria, Onitsha: Peoples Publishers.

[36] Uddi, P. J. (2009). Approaches to Conducting Scientific Research in Education, Arts and the Social Sciences. Online Journal of Education Research, 1(3), 44-56.

[37] Umaru, H. (1988). Science, Technology and Mathematics Education and Economic Development Okpara E. N. (ed). Education and National Stability. A Book of Reading by APQEN.

[38] Umuru, G. E. (2002). Re-Focusing Science Technology and Mathematics Education for Rapid National Development Refocusing Education in Nigeria A Book of Readings. 8(75).

[39] Uwaifo, V.O (2009). Technical education and its challenges in Nigeria in the 21st century. International NGO Journal 5(2) 40-44.

[40] Wimer, B. C. (2000). Issues and Contemporary problems of Technical Education in Nigeria, Owerri: Ahamzu Publishers.

Citation: Dr Ogunmola M.O, Ogunmola Oluwafemi Samuel. "The Influence of Vocational and Technical Education towards 6-3-3-4 System of Education for National Development" International Journal of Humanities Social Sciences and Education (IJHSSE), vol 8, no. 2, 2021, pp. 174-181. doi: https://doi.org/10.20431/2349-0381.0802017.

Copyright: (C) 2021 Authors. This is an open-access article distributed under the terms of the Creative Commons Attribution License, which permits unrestricted use, distribution, and reproduction in any medium, provided the original author and source are credited. 